\title{
Review of Literature on the Function and Allometric Relationships of Tree Stems and Branches
}

\author{
Gregory A. Dahle and Jason C. Grabosky
}

\begin{abstract}
The goal of maintenance pruning is the development of a tree canopy that meets a defined objective while minimizing the risk of failure. An indepth understanding of the primary functions of branches and how they influence canopy form is needed in order to assess the impacts of cultural practices such as pruning or plant spacing on canopy development. Allometric modeling describes the relationship between size and shape of organisms. This paper explores three allometric methods of modeling branch form (pipe model theory, fractal dimensioning, and power laws) and their potential in guiding pruning research. Additionally, two principal functions of plants—hydraulic and mechanical—are discussed in light of their impact of stem and branch form.

Key Words: Allometry; Biomechanics; Elastic Similarity, Hydraulics; Mechanics; Slenderness Ratio.
\end{abstract}

Arborists prune trees to develop and maintain canopy structure with the overall goal of maximizing canopy benefits while minimizing the risk of failure (Harris et al. 2004). It is hoped that the removal of tissue will direct growth in order to develop 'good' canopy structure. Good structure is subjective and can be difficult to define. Often the goal is to develop a stable canopy by removing undesirable structures and defects, such as co-dominant branching or branch unions with included bark (Gilman 2002; Gilman and Lilly 2008). Pruning can influence canopy form, and damaging wind, ice or cultural practices, such as topping, can deform a tree's canopy. Restoration pruning attempts to improve the structure and form of a damaged tree (American National Standards Institute 2008). The ultimate goal of restoration pruning is to return a damaged canopy to a condition where it can provide similar benefits to that of a 'natural' canopy with acceptable levels of risk of failure. The arborist has limited information on a formal definition of 'good' canopy structure and must rely on personal experience and intuition when deciding how to use pruning to guide canopy development or restoration. The underlying structure of a canopy rests on individual branch form, yet little is known on how to objectively and reliably predict canopy stability from branch form. The ability to define good canopy structure from branch form or better predict potential weaknesses could help the arborist direct growth and develop a more stable canopy.

Sullivan (1896) suggested that in building design, as well as in nature, form follows function. Niklas (1992) suggested that plants balance four functions throughout their lives: photosynthesis, reproduction, hydraulics, and mechanical support. While photosynthesis and reproduction are important, the hydraulics and mechanics are directly archived during growth. As a tree matures, the function of stems and branches presumably changes from primarily hydraulic (transporting water) to a balance between hydraulic and mechanics (resisting both static and dynamic loads) functions (Farnsworth and Niklas 1995; Woodrum et al. 2003). In order to survive, a tree must be capable of resisting self-applied and external loads. As a branch increases in size, mechanical support be- comes an increasingly important function particularly if hydraulic supply is not limiting (Niklas 1992; Spatz and Brüchert 2000).

The ability of trees to modify allocation in the functions of hydraulics and mechanics allows them to adapt overall form over time. Pruning removes tissue in the attempt to direct growth for a desired benefit and therefore shifts canopy form. Knowledge of form placed in a biological context can help the arboricultural community understand how to guide investment in growth and the shift in form. Plant biologists use allometry to describe the relationship between size and shape of organisms. Various allometric relationships have been developed to describe and predict growth patterns in trees. It is likely that the application of allometric modeling could aid researchers in the understanding of how a canopy develops and when, or if, a stable canopy form is reached.

This review is divided into two sections, beginning with a discussion of woody plant tissue function in terms of the roles of hydraulic and mechanical support in trees. In order to fully discuss these two functions, this paper will also briefly review some important aspects of woody plant anatomy at the tissue and cellular level. The second section discusses allometric modeling and reviews three allometric methods of describing tree form (pipe model theory, fractal dimensioning, and power laws), before discussing their potential applicability to arboricultural researchers and practitioners, particularly in terms of areas where additional research is warranted. The intent is to provide an overview of the literature for arboricultural researcher and practitioner, and inform discussions in the growing areas of pruning research, canopy modeling and preferred canopy structure in professional tree care, carbon/climate modeling, and risk management.

\section{FUNCTION OF WOODY PLANT TISSUE}

\section{Hydraulics}

Water is necessary for growth, photosynthesis, metabolic activity such as respiration, and the exchange of gases during transpira- 
tion (Kozlowski and Pallardy 1997). Understanding how a tree builds the system to deliver water is important to understanding the investment in this important function. Trees need to be able to pull water up long vascular networks to the distal leaves, and overcome the force of gravity. This flow occurs in the tracheids in gymnosperms and principally in the vessel elements of angiosperms. Tracheids cells play a dual role as the lumen serves as the location for water and nutrient transportation while the thick cell walls provide mechanical support (Panshin and de Zeeuw 1980; Sperry et al. 2006). Angiosperms typically separate these two functions between vessel members and fibers (Esau 1977; Sperry et al. 2006). Vessel members have thin cell walls that prevent local buckling, but add little if any structural support at the organ level (Cochard and Tyree 1990; Davis et al. 1999; Hacke and Sperry 2001; Hacke et al. 2006). The movement of water through tracheids and vessel lumens is similar to that of a pipe. It is slowest against the sidewalls due to adhesion, and increases parabolically towards the center of the cylinder (Tyree and Zimmermann 2002). This pattern is described by the HagenPoiseuille law of hydraulics (Equation 1), which shows that conductance is proportional to the fourth power of the radius of the cylinder if length is factored out. Since tracheids and vessels are not perfect pipes, the Hagen-Poiseuille equation overestimates conductance in trees. In order to pass from one conduit to the other, the water must pass through pit membranes (tracheids and vessels) and perforation plates (vessels) which reduce conductance. Researchers have compared conductance predicted by Hagen-Poiseuille to measured conductance and found that gymnosperms are only 26\%-43\% efficient (Zimmermann and Brown 1971 citing Ewart 1905 and Münch 1943) and angiosperms are 33\%-67\% efficient (Tyree and Zimmerman 1971; Petty 1978; Petty 1981). More recently, a decrease of $50 \%$ or more in efficiency has been attributed to the movement of water through the pits (Pittermann et al. 2006; Sperry et al. 2005; Choat et al. 2006; Choat et al. 2008). Although neither tracheids nor vessels are considered to be perfect cylinders, researchers suggest HagenPoiseuille is proportional to actual flow rates and that $r_{p}{ }^{4}$ provides a reasonable fit for theoretical conductance of water in xylem (Zimmermann 1978; Tyree et al. 1994; Tyree and Ewers 1991).

[Equation 1] $\quad K_{\text {capillary }}=\frac{r_{p}{ }^{4} P \pi}{8 n L}$

Where: $\mathrm{K}_{\text {capillary }}=$ hydraulic conductivity

$\mathrm{L}=$ length of conduit

$\eta=$ viscosity of liquid

$\mathrm{P}=$ hydraulic pressure head

$r_{p}=$ radius of conduit

The maximum diameter of vessels and tracheids tends to increase with cambial age (Fisher and Ewers 1995; Gartner et al. 1997; Domec and Gartner 2002; Sperry et al. 2006), although this was not true for holly oak (Quercus ilex L.) (Dünisch et al. 2004). Maximum conduit size is limited by embolisms (Tyree et al. 1994; Hacke and Sperry 2001; Gartner et al. 2003). The primary cause of embolisms is water stress, which creates large negative pressures that disrupts the cohesive water column (Ewers 1985). Addition- ally, embolisms occur if air bubbles form when water is frozen and not reabsorbed during thawing. Since smaller diameter conduits are less prone to embolism, it is likely that a balance between efficiency and risk occurs in regions prone to drought stress or freezing events during the growing season (Tyree and Zimmerman 2002).

Hydraulic conductivity has been found to decrease in favor of mechanical needs in both gymnosperms and angiosperms (Ewers 1985; Gartner et al. 1990; Spicer and Gartner 1998a; Spicer and Gartner 1998b). Mean vessel element diameter was found to be smaller in self-supported shrubs and vines than externally supported plants (Chiu and Ewers 1992; Gartner 1991a) and vessel diameter decreased in tension wood (Kaeiser and Boyce 1965; Jourez et al. 2001). Investment in mechanics at the expense of hydraulics appears to lead to increased radial growth (Gartner 1991a; Chiu and Ewers 1992). Subsequently, branch allometry will likely change with branches becoming less slender as mechanical support becomes more vital. Shifts in branch hydraulics and mechanics may lead to changes in branch form that could be identified with allometric modeling, such as power laws or slenderness ratios. Researchers may wish to investigate the applicability of allometric modeling to predict if a developing branch or watersprout appears to have a stable form and could be retained to serve as a scaffold, or removed due to a less stable form.

\section{Wood as a Mechanical Structure}

Understanding how wood imparts flexibility and strength is important in order to understand how trees withstand loads. Wood is an orthotropic structure, exhibiting different material properties with respect to the plane of applied loading (Panshin and de Zeeuw 1980). Wood is stronger in tension than compression (Panshin and de Zeeuw 1980; Reiterer et al. 1999). Unlike synthetic materials, wood maintains some mechanical strength beyond the elastic range which may explain why trees can remain standing after being subjected to extreme loads (Koehler and Telewski 2006).

Material properties of wood vary in accordance with many factors; among them are anatomical properties and moisture content. In green wood, moisture content is typically above $25 \%-30 \%$, and is considered the point at which fibers are saturated (Panshin and de Zeeuw 1980; Green et al. 1999); therefore, moisture content does not typically affect the material properties in live tissue. Woody plant cells are composed of a primary and secondary wall. The primary cell wall serves to confine and support the cell during development. The secondary cell wall is formed during cell maturation and adds important mechanical components that support the mature cell and stem/branch. The secondary cell wall has three layers (S1-S3) which are found interior to the primary wall.

Cellulose microfibrils provide tensile strength and vary in orientation with each layer and therefore influence the directional strength of the cell and tissue (Burgert 2006). In the outermost S1 layer, the microfibrils are oriented in the transverse direction and resist outward buckling, while microfibrils in the innermost S3 layer are oriented in the radial direction to prevent inward buckling (Esau 1977; Niklas 1992). The S2 layer provides the major mechanical support for the cell and the microfibrils are roughly aligned in the axial direction. A decrease in microfibril angle in the $\mathrm{S} 2$ layer (zero being parallel to the longitudinal axis) was shown to increase the strain (material displacement relative to original length) to fracture or toughness (Reiterer et al. 1999). Cells in young plants were found to have higher microfi- 
bril angles which allow flexibility (Lindström et al. 1998), while cells in mature wood have lower microfibril angles which makes them stiffer (Lichtenegger et al. 1999), and subsequently more resistant to deformation under load. The cellulose microfibrils are embedded in lignin (Esau 1977), and it is lignification that adds rigidity to plants and the ability to withstand compression (Koehler and Telewski 2006). Lignification indirectly increases tensile strength by impeding water which in turn would reduce the strength of the cellulose microfibrils (Niklas 1992). While the microfibril angle is useful in explaining strength patterns at the cellular level, measurements require destructive sampling and expensive laboratory testing which is probably not cost effective.

Modulus of elasticity $(E)$ is a material property of wood that describes resistance to bending and is commonly found in many engineering formulas. $E$ was found to be positively correlated with stem age (Niklas 1997a; Niklas 1997b; Niklas 1997c; Groom et al. 2002), decreased with stem height (Reiterer et al. 1999; Brüchert et al. 2000) and varied by branch diameter (Spatz and Brüchert 2000). Sapwood $E$ was $35 \%$ less than in heartwood, suggesting that younger stems and branches composed of sapwood are more flexible than wood composed predominately of heartwood (Niklas 1997a; Niklas; 1997b; Niklas 1997c; Spatz and Brüchert 2000). Values for $E$ in lumber quality green wood ( $>28 \%$ moisture content) and dried wood (12\% moisture content) are available in the literature, for example the Forest Products Laboratory's (FPL) Wood Handbook (Green et al. 1999).

The reported material properties in documents like the FPL Wood Handbook are derived from lumber quality wood that is free of defects, and are often greater than actual trees trunks, lateral branches or in wood located near the top of the trees (Pruyn et al. 2000; Woodrum et al. 2003; Kern et al. 2005; Kane 2007; Kane and Clouston 2008; Dahle 2009). Caution must be used when using material properties from such published data. It would be better to determine material properties empirically. This can be accomplished using a load press following ASTM D-143 specifications (American Society for Testing and Materials 2000) or cantilevered bend tests on small samples (Gartner 1991b; Wagner et al. 1998).

$E$ can be combined with the moment of inertia (I) to calculate flexural stiffness, which describes the ability of a beam to resist bending or a column to resist buckling (Niklas 1992, Niklas 1997b). $I$ is proportional to a beam's radius. For a circle, $I$ equals $0.25 \pi r^{4}$ and for an ellipse $0.25 \pi r_{y}^{3} r$, when bending across the $y$ plane (Hibbeler 2005). A beam with either a large cross-section or a high $E$ is more resistant to bending. The dominant factor in flexural stiffness is the radius of the column or beam. Brüchert et al. (2000) reported that flexural stiffness decreased with height. As such, the overall form of the stem or branch takes on an increasingly important role in how loads are resisted. Yet $E$ can not be ignored (Brüchert et al. 2000) since it varies with age, height, and diameter of the wood (Niklas 1997a; Niklas 1997b; Niklas 1997c; Reiterer et al. 1999; Brüchert et al. 2000; Spatz and Brüchert 2000; Groom et al. 2002). Niklas (1997b) suggests that the influence of a lower value for $E$ on flexural stiffness is most pronounced when the majority of a stem is comprised of sapwood as in young stems and in small branches. Indeed, Woodrum et al. (2003) found that both $E$ and $I$ were important in considering flexural stiffness in distal regions of branches. While the use of flexural stiffness can provide insight into the stability of stems and branches and radius is relatively easy to obtain, knowledge of how $E$ varies across a give cross-section is needed to accurately predict load carrying capacity (Brüchert et al. 2000). Researchers may wish to investigate how $E$ varies axially and radially to better estimate how much loading can be resisted by a stem or branch.

Reaction wood is found in both gymnosperms and angiosperms. In general, gymnosperms develop compression wood on the lower side of the leaning trunk or branch while angiosperms develop tension wood on the upper side. It has been noted that angiosperms may be capable of producing compression wood (Niklas 1992; Clair et al. 2006). Tracheids in compression wood have shorter cells with thicker cell walls (Panshin and de Zeeuw 1980). While both the S1 and S2 layers are thicker, the S2 layer contains less cellulose and more lignin (Côté et al. 1968; Parham and Côté 1971). Vessel elements in tension wood tend to be smaller and less numerous (Barefoot 1965), while fibers have thicker cell walls, smaller lumen diameters and are longer in length (Kaeiser and Boyce 1965). The widths of both S1 and S2 layers in fibers are smaller and a gelatinous layer is found interior to the secondary layers. This gelatinous layer is mainly composed of cellulose with limited lignin (Panshin and de Zeeuw 1980). Alméras et al. (2005) report that $E$ was greater in tension wood and less in compression wood in stem wood. Yet Dahle (2009) reported that presence of tension wood did not appear to affect $E$ in Norway maple (Acer platanoides L.) branch wood and was likely present to maintain branch orientation rather then actively re-orient the branches. Tension wood may be common in branches and has been observed along sections of entire branches that were comprised of secondary (radial) growth (Dahle 2009), yet the author only noted presence/absence of tension wood in the branches. Researchers may wish to investigate how the amount of tension wood present or thickness of the gelatinous layer influences the mechanical properties of branch wood. This knowledge would increase the understanding of how branches withstand loading events (both self-loading and external) and would likely aid practitioners when evaluating failure risk in urban trees.

The ability to provide structural support in trees lies in the composition and thickness of cell walls, or indirectly by the presence of lumens in tracheids, vessel members or fibers. Sone et al. (2006) reports that $E$ was positively correlated with percent fiber and fiber cell wall thickness in redvein maple (A. rufinerve Sieb. et Zucc.), while $E$ was found to be negatively correlated with fiber lumen diameter near the tips of branches in five species of Acer (Woodrum et al. 2003). Research has shown that anatomy is altered in response to mechanical needs (Kaeiser and Boyce 1965; Gartner 1991a; Chiu and Ewers 1992; Jourez et al. 2001), yet, it is not certain if this is a direct tradeoff between hydraulics and mechanics (Woodrum et al. 2003). More research is needed to determine how these important functions are balanced during normal branch development and if the balance leads to a predictable change in branch form. Pruning has a direct consequence on water use and load distribution along the branch. Pruning has a direct effect on branch form and may lead to changes in anatomical features such as cell wall width, lumen size or the formation of reaction wood in the future. Researchers may wish to investigate how management activities such as pruning affect subsequent development at the cellular and tissue levels which may then lead to changes in branch allometry and canopy stability. 


\section{ALLOMETRIC MODELING}

\section{Pipe Model Theory}

Pipe model theory predicts leaf biomass from stem size and is often used in carbon sequestration and canopy growth models (Berninger and Nikinmaa 1997; Chiba 1998; Mäkelä 2002). The stem is considered a 'unit pipe,' a nonphotosynthetic organ, which supports the leaves. The summation of the cross-sectional area of the stems at any given point predicts leaf mass (Equation 2) (Shinozaki et al. 1964). This equation is species-specific and may vary with region. The theory works well with smaller branches, but is less applicable towards the base of the tree as larger stems have a larger proportion of inactive wood (heartwood) (Berninger and Nikinmaa 1997; Suzuki and Hiura 2000; Taneda and Tateno 2004). The additive effect of increased amounts of tissue at branch junctions, due to hydraulic segmentation in the branch protection zone (Eisner et al. 2002) and circular vessels (Lev-Yadun and Aloni 1990) may have an impact on the robustness of the pipe model theory in larger branches and stems. While hydraulic segmentation and circular vessels serve to regulate the amount of water provided to the branch and protect the main stem from hydraulic failure, they lead to an increase in branch radius without necessarily increasing the amount of leaves or mechanical support.

[Equation 2] $\mathrm{M} \propto \sum_{s=1}^{n} \pi \mathrm{r}_{s}{ }^{2}$

Where: $\mathrm{M}=$ leaf mass

$n=$ number of stems or branches

$r_{s}=$ radius of stem or branch

Initially static, the pipe model was modified to account for heartwood formation and the subsequent removal of unused pipes (Mäkelä 2002). This has been incorporated into computer growth models such as a dichotomous threshold for heartwood formation in the LIGNUM and MORPHO models (Berezovskava et al. 1997; Perttunen et al. 1998), and a transitory manner in TREE and WHORL models (Mäkelä 2002). While such models have been used to simulate growth in an idealized conifer tree in a forest stand, it might be possible to incorporate them to investigate how pruning influences growth in amenity trees and individual branches. Pruning changes the form of a canopy, altering the amount of environmental loading (wind, ice, etc.) to which the tree is subjected, thus changing how the branch and stem react to the loading. Recent research has shown that trunk movement and bending moment varies with pruning dose or severity, and technique (Smiley and Kane 2006; Gilman et al. 2008a; Gilman et al. 2008b; Pavlis et al. 2008). Researchers may wish to investigate the applicability of these models in terms of growth responses to pruning and shifts in form and stability.

Determining pruning dose or severity is important in order to minimize the impact on tree health, yet it can be difficult to determine how much leaf biomass has been removed (Smiley and Kane 2006; Grabosky et al. 2007). A further adaptation of the pipe model has been used to estimate the amount of foliage removed during pruning, from branch cross-sectional area. Grabosky et al. (2007) suggests that while the cross-sectional area of branches can be used to estimate the amount of leaf area removed in small live oaks ( $Q$. virginiana Mill.), the summation of $r_{s}^{4}$ provided a more reliable explanation for model error than cross-sectional area along the trunk. The inclusion of $r^{4}$ may increase the power of predicting the mass of foliage growing on larger branches, leading to a better estimator of the amount of foliage on large branches and the whole tree. The current best management practices suggests that pruning dose or severity should not exceed $25 \%$ of the existing foliage (Gilman and Lilly 2008), researchers should continue to investigate the reliability of using branch radius, either $\mathrm{r}^{2}$ and/or $\mathrm{r}^{4}$, to estimate the mass of foliage removed and retained during pruning operations.

\section{Fractal Dimensioning}

Fractal dimensioning measures the relationships in self similar geometric shapes (La Barbera and Rosso 1989). The fractal dimension (D) is a description of how much two $(\mathrm{D}=2)$ or three $(\mathrm{D}=3)$ dimensional space is filled by the object(s) being modeled (Equation 3) (La Barbera and Rosso 1989).

[Equation 3] $\quad \mathrm{D}=\log \left(\mathrm{R}_{\mathrm{b}}\right) / \log \left(\mathrm{R}_{\mathrm{L}}\right)$

Where: $\mathrm{D}=$ fractal dimension

$\mathrm{R}_{\mathrm{b}}=$ bifurcation ratio

$\mathrm{R}_{\mathrm{L}}=$ link length ratio

$R_{b}$ is defined as the number of branches of order $N$ divided by the number of branches of the next order $(\mathrm{N}+1)$. Twigs are assigned an order of 1 , and where two twigs meet the result is branch of order 2 (La Barbera and Rosso 1989). $R_{L}$ is mean branch length for order $N$ divided by mean branch length for order N+1 (La Barbera and Rosso 1989).

Fractals have been incorporated in computer modeling of tree growth (Figure 1). Berezovskava et al. (1997) devised the MORPHO system which used Lindenmayer systems (L-systems) (Lindenmayer 1968) modeling to show that branch thickness depends on branch length in Norway spruce (Picea abies L. Karst.). Similarly, the L-PEACH model utilizes sourcesink relationships based on carbon and water to simulate growth based on water stress and fruit thinning (Allen et al. 2005). Although these models show it is possible to develop algorithms for computer modeling, L-systems and fractals have not been empirically tested (Casella and Sinoquet 2003; Percy et al. 2005).

Fractals can be useful in modeling overall geometric shape or space filling, but do not fully address branch dimensioning (Farnsworth and Niklas 1995; Casella and Sinoquet 2003). Fractals may be useful in describing the complexity of branching but the functional significance of fractals has not been fully determined (Fitter and Stickland 1992). Fractal analysis is best used when growth patterns are simple and continually repeating (Fitter and Stickland 1992), yet the literature suggests that the allometric pattern of branches is plastic (McMahon and Kronauer 1976; Bertram 1989; Farnsworth and Niklas 1995). The incorporation of fractal analysis in computer growth simulations may provide researchers a meaningful tool in exploring the nature of allometric plasticity and how a shift from small flexible leaf bearing branches to larger structural scaffold branches might influence canopy stability. Additionally, phyllotaxy (vegetative bud arrangement) results in a predictable lateral branch pattern which is gradually lost as young laterals naturally senesce (Maillette 1982; Wilson 1989; Suzuki and Hiura 2000). In developing urban canopy growth models, re- 
searchers may wish to incorporate adaptive fractals that can account for the departures from the original fractal pattern in urban canopy growth models based on various environmental loadings.

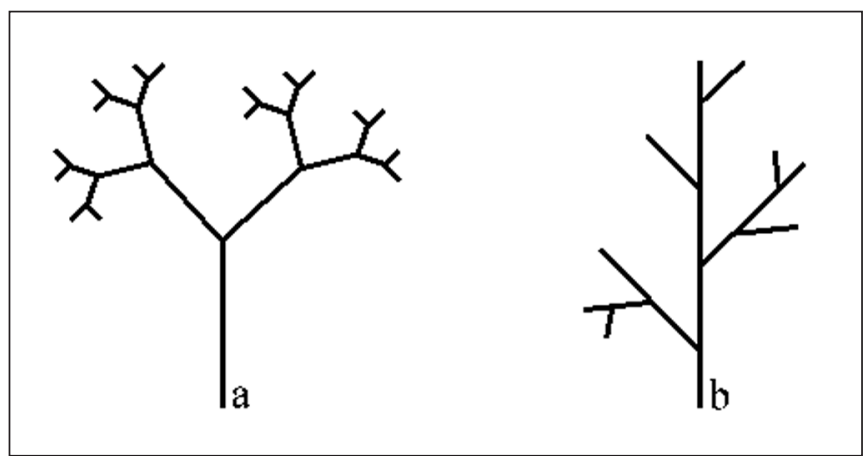

Figure 1. Depiction of fractal branching in (a) opposite (bifurcation) branching pattern, and (b) alternate branching pattern.

\section{Power Law Scaling}

Allometric research has often utilized $\log$-log relationships, or power laws $\left(\mathrm{Y} \propto \mathrm{aX} \mathrm{X}^{\mathrm{b}}\right.$ ), to investigate plant form (McMahon 1975; Niklas 1994a). One advantage power laws hold is the ability to investigate variation in the scalar (b) using regression analysis of the log-log transformed data. McMahon (1975) presented three models which utilize power laws to compare allometric patterns in trees using length (l) and radius ( $\mathrm{r}$ ) of the trunk: geometric similarity $\left(1 \propto \mathrm{r}^{1}\right)$, static stress similarity $\left(1 \propto \mathrm{r}^{1 / 2}\right)$ and elastic similarity $\left(1 \propto \mathrm{r}^{2 / 3}\right)$. Figure 2 depicts the three similarity models on a log$\log$ scale; therefore, the scalar (b) is presented as the slope coefficient.

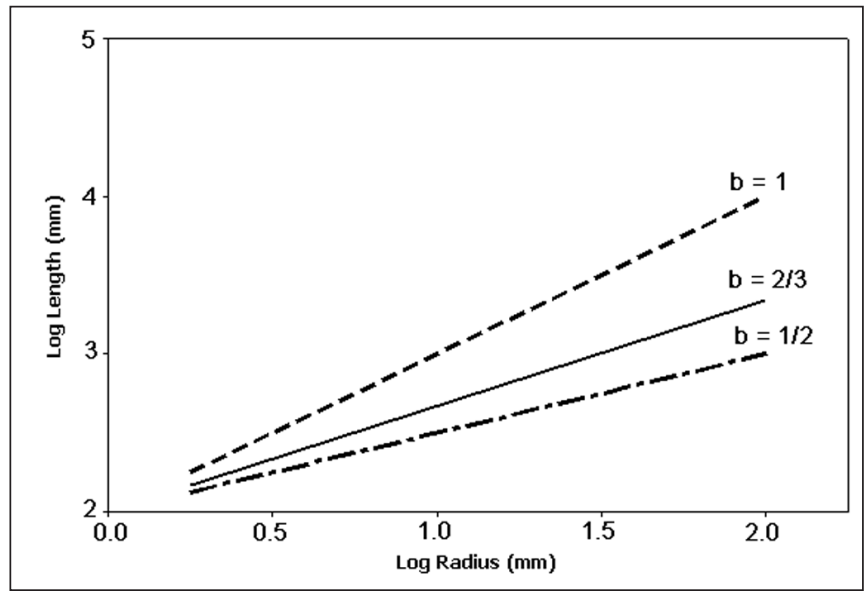

Figure 2. Theoretical log-log growth trajectories for length (I) versus radius $(r)$ of stems or branches following the similarity power law models $\left(I \propto r^{b}\right)$ forwarded by McMahon (1975): geometric similarity model $(b=1)$, elastic similarity model $(b=2 / 3)$, and static stress similarity model $(b=1 / 2)$.

The geometric similarity model suggests that the relationship between length and radius will remain the same as a tree grows in size. The geometric similarity model was found to fit many gymnosperms (Niklas 1994a), eight species in the genus Cecropia (Sposito and Santos 2001) and rainforest understory trees (Osunkoya et al. 2007). McMahon (1975) reported that perfectly scaled proto- types will often behave in a slightly different manner than the fullscale structure. Typically the models will need to have at least one physical parameter adjusted in order for the prototype to function as the full-scale structure. While both the static stress and elastic similarity models allow for such an adjustment in shape (as the exponent $b<1)$, the geometric similarity model $(b=1)$ does not.

The static stress similarity model $(b=1 / 2)$ suggests that length will scale to one-half of the stem radius, plus a fitting coefficient. This model was found to fit mature pine trees, both Scots (Pinus sylvestris L.) and lodgepole (P. contorta Dougl. ex. Loud.), as well as saplings of lodgepole pines (Dean and Long 1986; Mäkelä 2002), while the mature lodgepole pines trees were also fit with the elastic similarity model. The static stress similarity model has been known by a variety of names over the past century: concept of adaptive growth (Brüchert and Gardiner 2006 citing Schwendener 1874 and Metzger 1893), constant stress theory (Mattheck and Breloer 1994) and uniform stress theory (Morgan and Cannell 1994). These theories suggest that the shape of a tree stem is influenced by mechanical loading (Brüchert and Gardiner 2006). The uniform stress theory suggests that under average conditions mechanical stress (force per unit area) will be distributed uniformly on the outer fibers but non-uniformly during extreme conditions. McMahon (1975) suggested that only maximum stress is held constant between beams, but not average stress. Since stress levels have been found to vary along stems (Niklas and Spatz 2000; Ancelin et al. 2004; Kane et al. 2008) it has been suggested that the elastic similarity is a better model for tree stems (Niklas and Spatz 2000).

The elastic similarity model $(b=2 / 3)$ suggests that length will scale to two-thirds of the stem radius. McMahon and Kronauer (1976) present graphical data to support the elastic similarity model, although Niklas (1995) pointed out the graph represented a hand-drawn best-fit line rather than a regression analysis. Subsequent research reported the elastic similarity model held in many dicotyledonous trees (King 1986; Rich et al. 1986; Niklas 1994b; O'Brien et al. 1995), tropical trees above $6 \mathrm{~m}$ (20.4 ft) (King 1996) and midstory and canopy rainforest trees (Osunkoya et al. 2007).

The elastic similarity model is based on critical buckling length of a column (Equation 4) (Greenhill 1881) and suggests the critical length for a stem scales to the radius raised to the two-thirds power. This formula is derived from the Greenhill critical load to cause buckling of columns and not bending in cantilevered beams, although researchers have applied the elastic similarity model in studies of branch allometry (McMahon and Kronauer 1976; Bertram 1989; Spatz and Brüchert 2000).

[Equation 4] $\quad l_{\text {critical }}=C\left(\frac{E}{\rho}\right)^{\frac{1}{3}} r_{s}^{\frac{2}{3}}$

Where: $l_{\text {critical }}=$ Critical length

$C=$ Pritical Proportionality constant

$E=$ Modulus of elasticity

$\rho=$ Wood density

$\mathrm{r}_{\mathrm{s}}=$ Column radius at base

The proportionality constant $(C)$ was reported to be either 1.26 for cylinders without taper or 1.96 when tapered to a cone (Greenhill 1881). Additionally, $C$ should be calculated for complex shapes, non-uniformed materials, or to consider external 
loading (Spatz and Brüchert 2000). Density-specific stiffness

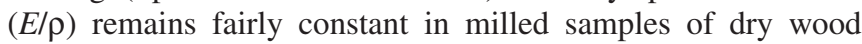
(Green et al. 1999; Panshin and de Zeeuw 1980), but was reported to vary in samples from live trees. The variation was due to transition from sapwood to heartwood (Niklas 1997a; Niklas 1997c), changes in anatomical properties such as microfibril angles in the S2 layer of secondary cell walls, percentage of latewood (Mencuccini et al. 1997), and stem slenderness (length/ radius) in four year old trees (Watt et al. 2006). The variation in density-specific stiffness in living wood has not been fully addressed with regards to the critical length formula (Equation 4) and researchers may wish to investigate the impact on stem/ branch form. Despite the potential variation in density-specific stiffness, many researchers continue to utilize the critical buckling formula (McMahon and Kronauer 1976; Bertram 1989; Niklas 1992; Spatz and Brüchert 2000; Niklas and Spatz 2004).

The application of this formula to trees is an example of how plant biomechanics incorporates engineering principles into the biological sciences. Niklas et al. (2006) provide a historical overview of this subject, suggesting that Schwendener's 1874 seminal monograph established the field of study. One of the primary goals for arborists is to minimize the risk of tree failure and research has turned towards biomechanics in an effort to better understand how trees withstand loading events (Dahle et al. 2006; Smiley and Kane 2006; Gilman et al. 2008a; Gilman et al. 2008b; Kane 2008; Kane and Clouston 2008; Kane et al. 2008). Researchers should investigate the applicability of McMahon's similarity models as a method to integrate allometry and biomechanical modeling to tree growing in the urban environment. The ability to better model and predict urban tree growth should increase the insight into how pruning can be utilized to direct growth toward the desired goal of a stable canopy form.

\section{Allometry of Branches}

It has been shown that none of the three similarity models (geometric, elastic, static stress) holds for trees or branches throughout their lives due to ontogenetic changes (Niklas 1994a; Niklas 1995; Osunkoya et al. 2007). The primary reason is that the rate of lateral elongation slows with age but radial growth is indeterminate and diminishes less over time. When plotted on a log-log scale, this growth pattern is described by a curvilinear relationship between height and radius in small plants that converges towards linear as plant size increases (McMahon and Kronauer 1976; Bertram 1989; Niklas 1995). This pattern was seen in branches where the elastic model was found to be robust when length was greater than $3 \mathrm{~m}(9.8 \mathrm{ft})$ in both white oak (Q. alba L.) and silver maple (A. saccharinum L.) (McMahon and Kronauer 1976; Bertram 1989), but not when branches were less than $3 \mathrm{~m}$. A depiction of this growth pattern can be seen in Figure 3 which is derived from a sub-sample of Norway maple branches which fit the curvilinear to linear relationship. Additionally many researchers have shown that the scalar changes when a plant grows from a small size or intermediate size (curvilinear > 2/3) to large (linear at 2/3) (McMahon and Kronauer 1976; Bertram 1989; Niklas 1995; Suzuki and Hiura 2000; Niklas and Spatz 2000; Niklas and Spatz 2004; Niklas 2007).

The transition in scalars is likely due to a change in flexibility, where smaller branches and trees tend to be more elastic and larger branches are stiffer (Niklas 1997a; Niklas 1997b;

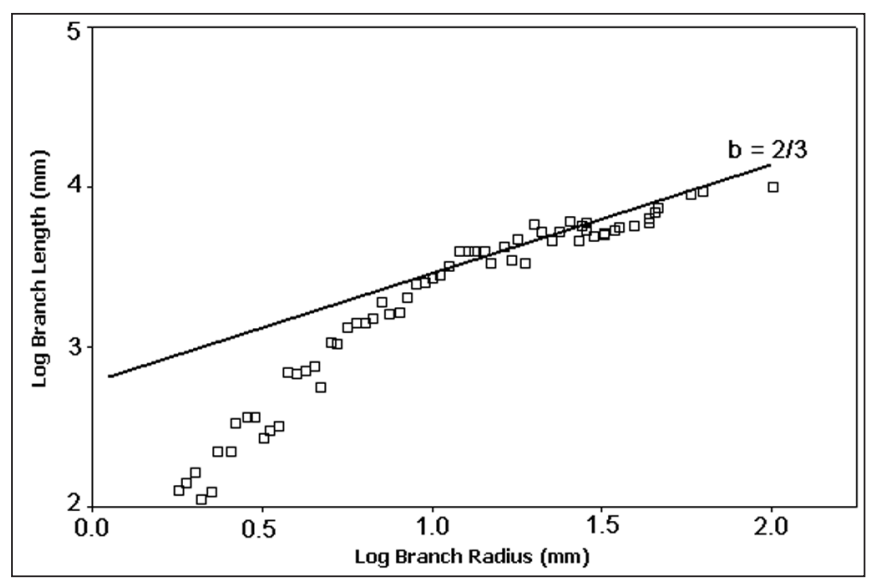

Figure 3. Log-log relationship between length and radius of a subset of Norway maple (Acer platanoides L.) depicting a curvilinear relationship for branches converging towards a linear relationship around $3 \mathrm{~m}(\log 3.48 \mathrm{~m}$, or $9.8 \mathrm{ft})$. The solid line depicts a length $=$ radius $^{2 / 3}$ as proposed by the elastic similarity model.

Niklas 1997c; Niklas and Spatz 2000). Smaller branches can reconfigure in heavy winds and a tree can afford to lose a number of smaller branches while larger branches are less flexible. The loss of even one large branch can be problematic either in terms of loss of photosynthetic capability or invasion points for decay organisms, which suggests that small branches can allocate more in elongation and hydraulics in order to place the leaves in the sun, while larger branches likely shift towards an increase in radial growth that balances hydraulics and mechanics.

Slenderness ratios (length/radius) have been used to define potential instability in trees and values above 200 are considered unstable in gymnosperms (Petty and Worrel 1981; Cremer et al. 1982; Petty and Swain 1985; Wang et al. 1998). Bertram (1989) reported that slenderness increased as silver maple branches grew in size to a maximum slenderness of 260 and then decreased. The change in slenderness corresponded to a shift to the elastic similarity model and the transition from flexible branches designed for solar collection to stiffer structural support branches. Osunkoya et al. (2007) found that slenderness did not differ between species but was greater in understory trees than in canopy or mid-canopy trees and was a better predictor of stem stability than wood density. If this pattern is consistent in branches, slenderness might prove useful in predicting instability in branches. Researchers may wish to investigate if this pattern holds for other species and empirically test the relationship between slenderness and branch stability.

At the stand level, slenderness often increases with competition and was found to be positively correlated with density-specific stiffness in Monterey pine ( $P$. radiata D. Don) plantations (Watt et al. 2006). It was suggested that the increase in densityspecific stiffness brought about more stability in slender stems. It is possible that resource competition is similar in an individual canopy and research should investigate if slenderness alone or in combination with a density-specific stiffness estimator could be used as a predictor of branch stability. Additionally, in restoration pruning arborists must selectively remove some watersprouts while retaining others. Dahle et al. (2006) found that that silver maple watersprouts were $49 \%$ weaker than normally growing lateral branches. This research only looked at watersprouts up to $21 \mathrm{~cm}(8.4 \mathrm{in})$ diameter and it is possible that material proper- 
ties may increase in the watersprouts at some point. Selection criteria for watersprout removal during restoration may be those with high slenderness ratios, although more research is needed to ascertain when slenderness is considered critically high in watersprouts. Arborists may also choose to use techniques like subordination to reduce slenderness ratios in waterspouts or branches. Researchers may wish to investigate if slenderness ratios can be used as predictor of instability in watersprouts or lateral branches.

\section{CONCLUSION}

It seems that Sullivan's (1896) observation applies to trees: form does indeed follow function. As trees grow a shift appears to occur in the balance between the functions of hydraulics and mechanics. Initially growth takes place with a greater investment in hydraulics. As such, young stems and branches are flexible and easily bend during loading events. Mechanics become more important over time, as implied by allocation of more energy in developing cell walls to provide increased mechanical support. The shift in function may coincide with a shift in plant form. The shift in form explains, in part, why the pipe model works well with smaller branches, but is less robust in larger branches. Fractal dimensioning also appears to be less robust when modeling tree canopies, yet the inclusion of adaptive fractals provide a promising avenue of research. The three similarity models put forth by McMahon (1975) and Niklas'(1992) suggestion that branches and stems transition between the models appear to best explain how tree stems and branches modify the relationship between lateral elongation and radial growth over time. Whether this shift is due to a tradeoff or a balance between hydraulics and mechanics has not been satisfactorily answered. Further research is needed to fully understand how form is influenced by hydraulic and mechanical functions. A better understanding between the form and function should help the arboricultural community improve maintenance pruning standards as well as devise guidelines for canopy restoration.

Over the past decade, arboricultural researchers have begun to model how tree response to moderate and extreme wind loading events is altered depending on pruning regimes (Smiley and Kane 2006; Gilman et al. 2008a; Gilman et al. 2008b; Pavlis et al. 2008). It is hoped that the information in this review, could be integrated with knowledge gained from such wind loading experiments in order to better understand how canopies are built to withstand the elements. The time is near when arboricultural researchers should consider utilizing the knowledge of branch form and mechanical structure to build a computer model of a representative amenity tree. This simulated tree could be integrated with data gained from on-going wind studies and then subjected to simulated loading events, such as hurricane force winds or ice loads. The simulated events could prove useful in developing predictions of canopy locations with inherent weakness. Researchers could then investigate how pruning techniques could be employed to increase canopy stability, both immediately and over time, as growth is added.

Acknowledgments. We would like to thank Drs. Peter Smouse, George Zimmermann, Ming Xu, and Edward Gilman for assistance during the preparation of this literature review. Dr. Brian Kane and a series of anonymous reviewers provided critical advice which strengthened this manuscript. Kim Sorvig for a robust conversation regarding adaptive fractals. This effort was funded by the John \& Eleanor Kuser Faculty Scholar Endowment.

\section{LITERATURE CITED}

Allen, M.T., P. Prusinkiewicz, and T.M. DeJong. 2005. Using L-systems for modeling source-sink interactions, architecture and physiology of growing trees: the L-PEACH model. New Phytologist 166:869-880.

Alméras, T., A. Thibaut, and J. Gril. 2005. Effect of circumferential heterogeneity of wood maturation strain, modulus of elasticity and radial growth on the regulation of stem orientation in trees. Trees: Structure Function 19:457-467.

American National Standards Institute. 2008. American National Standards for Tree Care Operations-Tree, Shrub, and Other Woody Plant Maintenance-Standard Practices (Pruning) (A300 Part 1). Tree Care Industry Association, Manchester, $\mathrm{NH}$.

American Society for Testing and Materials. 2000. Standard test methods for small clear speciments of timber (D143-95, Reapproved 2000). ASTM International, West Conshohocken PA.

Ancelin, P., B. Courbaud, and T. Fourcaud, 2004. Development of an individual tree based mechanical model to predict wind damage within forest stands. Forest Ecology Management 203:102-121.

Barefoot, M.W. 1965. Influence of cellulose, lignin and density on toughness of yellow poplar. Forest Products Journal 15:46-49.

Berezovskava, F.S., G.P. Karev, O.S. Kisliuk, R.G. Khlebopros, and Y.L. Tsel'niker. 1997. A fractal approach to computer-analytical modeling of tree crowns. Trees: Structure and Function 11:323-327.

Berninger, F., and E. Nikinmaa. 1997. Implications of varying pipe model relationships on Scots pine growth in different climates. Functional Ecology 11:146-156.

Bertram, J.E.A. 1989. Size-dependent differential scaling in branches: the mechanical design of trees revisited. Trees: Structure and Function $4: 241-253$

Brüchert, F., and B. Gardiner. 2006. The effect of wind exposure on the tree aerial architecture and biomechanics of Sitka spruce (Picea sitchensis, Pinaceae). American Journal of Botany 93:1512-1521.

Brüchert, F., F. Becker, and T. Speck. 2000. The mechanics of Norway spruce [Picea abies (L.) Karst]: mechanical properties of standing trees from different thinning regimes. Forest Ecology and Management 135:45-62.

Burgert, I. 2006. Exploring the micromechanical design of plant cell walls. American Journal of Botany 93:1391-1401.

Casella, E., and H. Sinoquet. 2003. A method for describing the canopy architecture of coppice poplar with allometric relationships. Tree Physiology 23:1153-1170.

Chiba, Y. 1998. Architectural analysis of relationship between biomass and basal area based on pipe model theory. Ecological Modelling 108:219-225.

Chiu, S.T., and F.W. Ewers. 1992. Xylem structure and water transport in a twiner, a scrambler, and a shrub of Lonicera (Caprifoliaceae). Trees: Structure and Function 6:216-224

Choat, B., T.W. Brodie, A.R. Cobb, M.A. Zwieniecki, and N.M. Holbrook. 2006. Direct measurements of intervessel pit membrane hydraulic resistance in two angiosperm tree species. American Journal of Botany 93:993-1000.

Choat, B., A.R. Cobb, and S. Jansen. 2008. Structure and function of bordered pits: new discoveries and impacts on whole-plant hydraulic function. New Phytologist 177:608-626.

Clair, B., R. Almeras, and J. Sugiyama. 2006. Compression stress in opposite wood of angiosperms: observations in chestnut, mani and polar. Annals of Forest Science 63:507-510.

Côté, W.A., Jr., A.C. Day, and T.E. Timell. 1968. Distribution of lignin in normal and compression wood of tamarack. Wood Science and Technology 2:13-37. 
Cochard, H., and M.T. Tyree. 1990. Xylem dysfunction in Quercus: vessel sizes, tyloses, cavitation and seasonal changes in embolism. Tree Physiology 6:393-407.

Cremer, K.W., C.J. Borough, F.H. McKinnell, and P.R. Carter. 1982. Effects of stocking and thinning on wind damage in plantations. New Zealand Journal of Forestry Science 12:244-268.

Dahle, G.A. 2009. How the hydraulic and mechanical properties of wood influence branch form in Norway maple (Acer platanoides L.). Ph.D. Dissertation. Rutgers University, New Brunswick NJ.

Dahle, G.A., H.H. Holt, W.R. Chaney, T.M Whalen, D.L. Cassens, R. Gazo, and R.L. McKenzie. 2006. Branch strength loss implications for silver maple (Acer saccharinum) converted from round-over to V-trims. Arboriculture \& Urban Forestry 32:148-154.

Davis, S.D., J.S. Sperry, and U.G. Hacke. 1999. The relationship between xylem conduit diameter and cavitation caused by freezing events. American Journal of Botany 86:1367-1372.

Dean, T.J., and J.N Long. 1986. Validity of constant-stress and elasticinstability principles of stem formation in Pinus contorta and Trifolium pratense. Annals of Botany 58:533-840.

Dünisch, O., C.B. Reissmann, and A. Oliszeski. 2004. Variability of vessel characteristics in the xylem of Ilex paraguariensis (Mate-tree) from south Brazil. IAWA Journal 25:449-458.

Domec, J.C., and B.L. Gartner. 2002. Age- and position-related changes in hydraulic versus mechanical dysfunction of xylem: inferring the design criteria for Douglas-fir wood structure. Tree Physiology 22:91-104.

Eisner, N.J., E.F. Gilman, J.C. Grabosky, and R.C. Beeson Jr. 2002. Branch junction characteristics affect hydraulic segmentation in red maple. Journal of Arboriculture 28:245-251.

Esau, K. 1977. Anatomy of seed plants. John Wiley and Sons, New York, New York.

Ewers, F.W. 1985. Xylem structure and water conduction in conifer trees, dicot trees, and lianas. IAWA Bulletin 6:309-317.

Farnsworth, K.D., and K.J. Niklas. 1995. Theories of optimization, form and function in branching architecture of plants. Functional Ecology 9:355-363.

Fisher, J.B., and F.W. Ewers 1995. Vessel dimensions in liana and tree species of Gnetum (Gnetales). American Journal of Botany 82: $1350-1357$

Fitter, A.H., and T.R. Stickland. 1992. Fractal characterization of root system architecture. Functional Ecology 6:632-635.

Gartner, B.L. 1991a. Stem hydraulic properties of vines vs. shrubs of western poison oak, Toxicodendron diversilobum. Oecologia 87:180-189.

Gartner, B.L. 1991b. Structural stability and architectural of vines vs. shrubs of poison oak, Toxicodendron diversilobum. Ecology 76:2005-2015.

Gartner, B.L., S.H. Bullock, H.A. Mooney, V.B. Brown, and J.L. Whitbeck. 1990. Water transport properties of vine and tree stems in a tropical deciduous forest. American Journal of Botany 77:742-749.

Gartner, B.L., H. Lei., and M.R., Milota. 1997. Variation in the anatomy and specific gravity of wood within and between trees of red alder (Alnus rubra Bong.). Wood and Fiber Science 29:10-20.

Gartner, B.L., J. Roy, and R. Huc. 2003. Effects of tension wood on specific conductivity and vulnerability to embolism of Quercus ilex seedlings grown at two atmospheric $\mathrm{CO}_{2}$ concentration. Tree Physiology 23:387-395.

Gilman, E.F. 2002. An Illustrated Guide to Pruning. Delmar, Albany, NY.

Gilman, E.F., and S. Lilly. 2008. Best management practices: pruning, second edition. International Society of Arboriculture, Champaign IL.
Gilman, E.F., J.C Grabosky, S. Jones, and C. Harchick. 2008a. Effects of pruning dose and type on trunk movement in tropical storm winds. Arboriculture \& Urban Forestry 34:13-19.

Gilman, E.F., F. Masters, and J.C. Grabosky. 2008b. Pruning affects tree movement in hurricane force wind. Arboriculture \& Urban Forestry 34:20-28.

Grabosky, J., E. Gilman, and C. Harchick. 2007. Use of branch crosssectional area for predicting pruning dose in young field-grown $Q u e r-$ cus virginiana 'Cathedral' in Florida, US. Urban Forestry and Urban Greening 6:159-167.

Green, D.W., J.E. Winandy, and D.E. Kretschmann. 1999. Mechanical properties of wood. In: Wood Handbook: Wood as an Engineering Material. General Technical Report FPL-GTR-113. USDA, Forest Products Laboratory, Madison, WI.

Greenhill, A.G. 1881. Determination of the greatest height consistent with stability that a vertical pole or mast can be made, and of the greatest height to which a tree of given proportions can grow. Proceedings of the Cambridge Philosophical Society 4:65-73.

Groom, L., L. Mott, and S. Shaler. 2002. Mechanical properties of individual southern pine fibers. Part I. Determination and variability of stress-strain curves with respect to tree height and juvenility. Wood and Fiber Science 34:14-27.

Hacke, U.G., and J.S. Sperry. 2001. Functional and ecological xylem anatomy. Perspective Plant Ecology 4:97-115.

Hacke, U.G., J.S. Sperry, J.K Wheeler, and L. Castro. 2006. Scaling of angiosperm xylem structure with safety and efficiency. Tree Physiology 26:689-701.

Harris, R.W., J.R. Clark, and N.P. Matheny. 2004. Arboriculture, integrated management of landscape trees, shrubs, and vines. Prentice Hall, Upper Saddle River, NJ.

Hibbeler, RC. 2005. Mechanics of Material 6th Edition. Pearson Prentice Hall, Upper Saddle River, NJ.

Jourez, B., A. Riboux, and A. LeClercq. 2001. Anatomical characteristics of tension wood and opposite wood in young inclined stems of poplar (Populus euramericana cv "Ghoy") IAWA Journal 22:133-138.

Kaeiser, M., and S.G. Boyce. 1965. The relationship of gelatinous fibers to wood structure in eastern cottonwood (Populus deltoids). American Journal of Botany 52:711-715.

Kane, B. 2007. Branch strength of bradford pear (Pyrus calleryana var. 'Bradford'). Arboriculture \& Urban Forestry 33:283-291.

Kane, B. 2008. Tree failure following a windstorm in Brewster Massachusetts, USA. Urban Forestry and Urban Greening 7:15-23.

Kane, B., and P. Clouston. 2008. Tree pulling tests of large shade trees in the genus Acer. Arboriculture \& Urban Forestry 34:101-109.

Kane, B., M. Pavlis, J.R. Harris, and J.R. Seiler. 2008. Crown reconfiguration and trunk stress in deciduous trees. Canadian Journal of Forest Research 38:1275-1289.

Kern, K.A., F.W. Ewers, F.W. Telewski, and L. Koehler. 2005. Mechanical perturbation affects conductivity, mechanical properties and aboveground biomass of hybrid poplars. Tree Physiology 25:1243-1251.

King, D.A. 1986. Tree form, height growth, and susceptibility to wind damage in Acer saccharum. Ecology 67:980-990.

King, D.A. 1996. Allometry and life history of tropical trees. Journal of Tropical Ecology 12:25-44.

Koehler, L., and F.W. Telewski. 2006. Biomechanics and transgenic wood. American Journal of Botany 93:1433-1438.

Kozlowski, T.T., and S.G. Pallardy. 1997. Physiology of wood plants. Academic Press, Inc. San Diego, CA.

La Barbera, P., and R. Rosso. 1989. On the fractal dimension of stream networks. Water Resources Research 25:735-741. 
Lev-Yadun, S., and R. Aloni. 1990. Vascular differentiation in branch junctions of trees: circular patterns and fuctional significance. Trees: Structure Function 4:49-54.

Lichtenegger, H., A. Reiterer, S.E. Stanzl-Tschegg, and P. Fratzl. 1999. Variation of cellulose microfibril angles in softwoods and hardwoodsa possible strategy of mechanical optimization. Journal of Structural Biology 128:257-269.

Lindenmayer, A. 1968. A mathematical model for cellular interactions in development I. Filaments with one-sided inputs. Journal of Theoretical Biology 18:280-299.

Lindström, H., J.W. Evans, and S.P. Verrill. 1998. Influence of cambial age and growth conditions on microfibril angle in young Norway spruce (Picea abies [L.] Karst). Holzforschung 52:573-581.

Maillette, L. 1982. Structural dynamics of silver birch I. The fates of buds. Journal of Applied Ecology 19:203-218.

Mäkelä, A. 2002. Derivation of stem taper from the pipe theory in a carbon balance framework. Tree Physiology 22:891-905.

Mattheck, C., and H. Breloer. 1994. The body language of trees: A handbook of failure analysis. The Stationary Office. London, UK.

McMahon, T.A. 1975. Using body size to understand the structural design of animals: quadrupedal locomotion. Journal of Applied Physiology 39:619-627.

McMahon, T.A., and R.E. Kronauer. 1976. Tree structures: Deducing the principle of mechanical design. Journal of Theoretical Biology 59:443-466.

Mencuccini, M., J. Grace, and M. Fioravanti. 1997. Biomechanical and hydraulic determinants of tree structure in Scots pine: anatomical characteristics. Tree Physiology 17:105-113.

Morgan, J., and G.R. Cannell. 1994. Shape of tree stems: a reexamination of the uniform stress hypothesis. Tree Physiology 14:49-62.

Niklas, K.J. 1992. Plant biomechanics: an engineering approach to plant form and function. University of Chicago Press, Chicago, IL.

Niklas, K.J. 1994a. Allometry: the scaling of form and process. University of Chicago Press. Chicago, IL.

Niklas, K.J. 1994b. Interspecific allometries of critical buckling height and actual plant height. American Journal of Botany 81:1275-1279.

Niklas, K.J. 1995. Size-dependent allometry of tree height, diameter and trunk-taper. Annals of Botany 75:217-227.

Niklas, K.J. 1997a. Mechanical properties of black locust (Robinia pseudoacacia L.) wood. Size- and age-dependent variation in sapand heartwood. Annals of Botany 79:265-272.

Niklas, K.J. 1997b. Size- and age-dependent variation in the properties of sap- and heartwood in black locust (Robinia pseudoacacia L.) Annals of Botany 79:473-478.

Niklas, K.J. 1997c. Mechanical properties of black locust (Robinia pseudoacacia L.) wood: correlations among elastic and rupture moduli, proportional limit, and tissue density and specific gravity. Annals of Botany 79:479-485.

Niklas, K.J. 2007. Maximum plant height and the biophysical factors that limit it. Tree Physiology 27:433-440.

Niklas, K.J., and H.-C. Spatz. 2000. Wind-induced stresses in cherry trees: evidence against the hypothesis of constant stress levels. Trees: Structure and Function 14:230-237.

Niklas, K.J., and H.-C. Spatz. 2004. Growth and hydraulic (not mechanical) constraints govern the scaling of tree height and mass. Proceedings of the National Academy of Sciences 101:15661-15663.

Niklas, K.J., H.-C. Spatz, and J. Vincent. 2006. Plant biomechanics: An overview and prospectus. American Journal of Botany 93: 1369-1378.
O’Brien, S.T., S.P. Hubbell, P. Spiro, R. Condit, and R.B Foster. 1995. Diameter, height, crown, and age relationships in eight neotropical tree species. Ecology 76:1926-1939.

Osunkoya, O.O., K. Omar-Ali, N. Amit, J. Dayan, D.S. Daud, and T.K. Sheng. 2007. Comparative height-crown allometry and mechanical design in 22 tree species of Kuala Belalong rainforest, Brunei, Borneo. American Journal of Botany 94:1951-1962.

Panshin, A.J., and C. de Zeeuw. 1980. Textbook of wood technology. McGraw-Hill, New York, New York.

Parham, R.A., and W.A. Côté. 1971. Distribution of lignin in normal and compression wood of Pinus taeda L. Wood Science and Technology 5:49-62.

Pavlis, M., B. Kane, J.R. Harris, and J.R. Seiler. 2008. The effects of pruning on drag and bending moment of shade trees. Arboriculture and Urban Forestry 34:207-215.

Percy, R.W., H. Muraoka, and F. Valladares. 2005. Crown architecture in sun and shade environments: assessing function and trade-offs with a three-dimensional simulation model. New Phytologist 166:791-800.

Perttunen, J., R. Sievänen, and E. Nikinmaa. 1998. LIGNUM: a model combining the structure and the functioning of trees. Ecological Modelling 108:189-198

Petty, J.A. 1978. Fluid flow through the vessels of birch wood. Journal of Experimental Botany 29:1463-1469.

Petty, J.A. 1981. Fluid flow through the vessels and intervascular pits of sycamore wood. Holzforschung 35:213-216.

Petty, J.A., and C. Swain. 1985. Factors influencing stem breakage of conifers in high winds. Foresty 58:75-84.

Petty, J.A., and R. Worrell. 1981. Stability of coniferous tree stems in relation to damage by snow. Forestry 54:115-128.

Pitterman, J., J.S. Sperry, J.K. Wheeler, U.G. Hacke, and E.H. Sikkema. 2006. Mechanical reinforcement of tracheids compromises the hydraulic efficiency of conifer xylem. Plant, Cell and Environment 29:1618-1628.

Pruyn, M.L., B.J. Ewers III, and F.W. Telewski. 2000. Thigmomorphogenesis: changes in the morphology and mechanical property of two Populus hybrids in response to mechanical perturbation. Tree Physiology 20:535-540.

Reiterer, A., H. Lichtenegger, S. Tschegg, and P. Fratzl. 1999. Experimental evidence for a mechanical function of the cellulose microfibril angle in wood cell walls. Philosophical Magazine A 79:2173-2184.

Rich, P.M., K. Helenurm, D. Kearns, S.R. Morse, M.W. Palmer, and L. Short. 1986. Height and stem diameter relationships for dicotyledonous trees and arborescent palms of Costa Rican tropical wet forest. Bulletin of the Torrey Botanical Club 113:241-246.

Shinozaki, K., K. Yoda, K. Hozumi, and T. Kira. 1964. A quantitative analysis of plant form - The pipe model theory I. Basic Analyses. Japanese Journal of Ecology 14:97-104.

Smiley, E.T., and B. Kane. 2006. The effects of pruning type on wind loading of Acer rubrum. Arboriculture \& Urban Forestry 32:33-40.

Sone, K., K. Noguchi, and I. Terashima. 2006. Mechanical and ecophysiological significance of the form of a young Acer rufinerve tree: vertical gradient in branch mechanical properties. Tree Physiology 26:1549-1558.

Spatz, H.C., and F. Brüchert. 2000. Basic biomechanics of self supporting plants: wind and gravitational loads on a Norway spruce tree. Forest Ecology Management 135:33-44.

Sperry, J.S., U.G. Hacke, and J.K Wheeler. 2005. Comparative analysis of end wall resistivity in xylem conduits. Plant, Cell and Environment $28: 456-465$. 
Sperry, J.S., U.G. Hacke, and J. Pittermann. 2006. Size and function in conifer tracheids and angiosperm vessels. American Journal of Botany 93:1490-1500.

Spicer, R., and B.L. Gartner. 1998a. How does a gymnosperm branch (Pseudotsuga menziesii) assume the hydraulic status of a main stem when it takes over as a leader? Plant Cell Environment 21:10631070.

Spicer, R., and B.L. Gartner 1998b. Hydraulic properties of Douglas-fir (Pseudotsuga menziesii) branches and branch halves with reverence to compression wood. Tree Physiology 18:777-784.

Sposito, T.C., and F.A.M. Santos. 2001. Scaling of stem and crown in eight Cecropia (Cecropiaceae) species of Brazil. American Journal of Botany 88:939-949.

Sullivan, L.H. 1896. The tall office building artistically considered. Loppincott's Magazine. Cited from: http://www.njit.edu/v2/Library/archlib/pub-domain/sullivan-1896-tall-bldg.html, Accessed $10 / 22 / 2007$.

Suzuki, M., and T. Hiura. 2000. Allometric differences between currentyear shoots and large branches of deciduous broad-leaved tree species. Tree Physiology 20:203-209.

Taneda, H., and M. Tateno. 2004. The criteria for biomass partitioning of the current shoot: water transport versus mechanical support. American Journal of Botany 91:1949-1959.

Tyree, M.T., S.D. Davis, and H. Cochard. 1994. Biophysical perspectives of xylem evolution: is there a tradeoff of hydraulic efficiency for vulnerability to dysfunction? IAWA Journal 15:335-360.

Tyree, M.T., and F.W. Ewers. 1991. The hydraulic architecture of trees and other woody plants. New Phytologist 119:345-360.

Tyree, M.T., and M.H. Zimmermann. 1971. The theory and practice of measuring transport coefficients and sap flow in the xylem of red maple stems (Acer rubrum). Journal of Experiments Botany 22:1-18.

Tyree, M.T., and M.H. Zimmermann. 2002. Xylem structure and the ascent of sap. Second Edition. Springer-Verlag, New York, New York.

Wagner, K.R., F.W. Ewers, and S.D. Davis. 1998. Tradeoffs between hydraulic efficiency and mechanical strength in the stems of four cooccurring species of chaparral shrubs. Oecologia 117:53-62.

Wang, Y., S.J. Titus, and V.M LeMay. 1998. Relationships between tree slenderness coefficients and tree or stand characteristics for major species in boreal mixedwood forests. Canadian Journal of Forest Research 28:1171-1183.

Watt, M.S., J.R. Moore, J-P. Facon, G.M. Downes, P.W. Clinton, G. Coker, M.R. Davis, R. Simcock, R.L. Parfitt, J. Dando, E.G. Mason, and H.E. Bown. 2006. Modelling environmental variation in young's modulus for Pinus radiata and implications for determination of critical buckling height. Annals of Botany 98:765-775.

Wilson, B.F. 1989. Tree branches as populations of twigs. Canadian Journal of Botany 67:434-442.

Woodrum, C.L., F.W. Ewers, and F.W. Telewski. 2003. Hydraulic, biomechanical and anatomical interactions of xylem from five species of Acer (Aceraceae). American Journal of Botany 90:693-699.

Zimmermann, M.H. 1978. Hydraulic architecture of some diffuse porous trees. Canadian Journal of Botany 56:2286-2295.

Zimmermann, M.H., and C.L. Brown. 1971. Trees structure function. Springer-Verlag, New York, New York.
Gregory A. Dahle (corresponding author)

Post-Doctorate Researcher

Rutgers University

Department of Ecology, Evolution and Natural Resources

14 College Farm Road

New Brunswick, NJ 08901, U.S.

book2088@yahoo.com

Jason C. Grabosky

Associate Professor

Rutgers University

Department of Ecology, Evolution and Natural Resources

14 College Farm Road, Room 144

New Brunswick, NJ 08901, U.S.

Résumé. Le but de l'élagage d'entretien est de développer un couvert arboré qui rencontre un objectif défini tout en minimisant les risques de bris. Une compréhension intime des fonctions primaires des branches et comment elles influencent la forme du couvert végétal s'avère nécessaire afin d'évaluer les impacts des pratiques culturales telles que l'élagage ou l'espacement entre les arbres, et ce par rapport au développement du couvert arboré. La modélisation allométrique décrit la relation entre la dimension et la forme des organismes. Cet article explore trois méthodes allométriques de modélisation de la forme de la branche (modèle théorique du tuyau, dimension fractale, principes de puissance) et leur potentiel pour guider la recherche sur l'élagage. De plus, deux fonctions principales de la plante—hydraulique et mécanique—sont discutées à la lumière de leur impact sur la forme de la branche et de la tige.

Zusammenfassung. Das Ziel beim Erhaltungsschnitt ist die Entwicklung einer Baumkrone, die eine definierte Erscheinung erhält, während die Gefahren des Versagens minimiert werden. Ein tiefes Verständnis für die primären Funktionen von Ästen und wie diese die Kronenform beeinflussen, ist erforderlich, um die Auswirkungen von Kulturmaßnahmen, wie Rückschnitt oder Pflanzabstand, auf die Kronenbildung zu untersuchen. Allometrische Modelle beschreiben die Relation zwischen Größe und Form von Organismen. Diese Studie untersucht drei allometrische Modelle von der Astformung (Pfeifenmodell-Theorie, Fraktale Dimension und Kraftgesetze) und ihr Potential, Forschung im Bereich von Rückschnitt zu unterstützen. Zusätzlich wurden zwei prinzipielle Funktionen von Pflanzen (hydraulisch und mechanisch) in dem Licht ihres Einflusses auf Stamm- und Astform diskutiert.

Resumen. El objetivo de la poda de mantenimiento es el desarrollo de una copa del árbol que satisfaga un propósito definido mientras minimice el riesgo de falla. Un entendimiento de las funciones primarias de las ramas y cómo influyen en la forma de la copa es necesaria con el fin de evaluar el impacto de las prácticas culturales tales como poda o espaciamiento de plantas en el desarrollo de la copa. El modelamiento alométrico describe las relaciones entre tamaño y forma de organismos. Este reporte explora tres métodos alométricos de modelamiento de la forma de las ramas (modelo teórico tubular, dimensionamiento fractal y leyes de poder) en su potencial en investigación guía de la poda. Adicionalmente, dos funciones principales de las plantas-hidráulica y mecánica — son discutidas a la luz de sus impactos en la forma de tallos y ramas. 